\title{
Enhancing Museum Narratives: Tales of Things and UCL's Grant Museum
}

\section{Claire Ross, Mark Carnall, Andrew Hudson-Smith, Claire Warwick, Melissa Terras and Steven Gray}

Emergent mobile technologies offer museum professionals new ways of engaging visitors with their collections. Museums are powerful learning environments and mobile technology can enable visitors to experience the narratives in museum objects and galleries and integrate them with their own personal reflections and interpretations. UCL's QRator project is exploring how handheld mobile devices and interactive digital labels can create new models for public engagement, personal meaning making and the construction of narrative opportunities inside museum spaces. The use of narrative in museums has long been recognised as a powerful communication technique to engage visitors and to explore the different kinds of learning and participation that result. Many museums make extensive use of narrative, or storytelling, as a learning, interpretive, and meaning making tool. It has been suggested that;

"Every museum visitor is a storyteller with authority. Every evocative object on exhibit is a mnemonic device. Every visitor interaction is story-making as visitors fit portions of our collections into personal frames of reference; most often in ways we neither intended nor anticipated."1

Nevertheless digital technologies, specifically mobile media, have rarely been used by museums to facilitate collaborative construction of narrative and meaning making.

Museums have undergone a fundamental shift from being primarily a presenter of objects to being a site for experiences which offer visitors opportunities for individual meaning making and narrative creation. Many visitors expect or want to engage with a subject, physically as well as personally ${ }^{2}$. Visitors see interactive technology as an important stimulus for learning and engagement ${ }^{3}$, empowering users to construct their own narratives in response to museum exhibits. Beyond expected content synthesis, these immersive activities can stimulate learning. Engaged within this immersive environment, museum objects become rich sources of innovation and personal growth ${ }^{4}$. When visitors experience a museum which encourages individual narrative construction actively, their activity is directed not towards the acquisition or receipt of the information being communicated by the museum, 
but rather towards the construction of a very personal interpretation of museum objects and collections. The unpredictability of multiple narrative forms created by the use of mobile devices and interactive labels introduces new considerations to the process by which museums convey object and collection interpretation and opens up museums to become a more engaging experience.

This chapter discusses the potential for mobile technologies to connect museums to audiences through co-creation of narratives, taking the QRator project as a case study. The QRator project aims to stress the necessity of engaging visitors actively in the creation of their own interpretations of museum collections through the integration of QR codes, iPhone, iPad, and Android apps into UCL's Grant Museum of Zoology. Although this chapter will concentrate on mobile technology created for a natural history museum, issues of meaning making and narrative creation through mobile technology are applicable to any discipline. In the first instance, the concern is with the development of mobile media in museums followed by a discussion of the QRator project which stresses the opportunities and challenges in utilizing mobile technology to enhance visitor meaning making and narrative construction. Finally, this chapter discusses the extent to which mobile technologies might be used purposefully to transform institutional cultures, practices and relationships with visitors.

\section{Mobile Media in Museums}

Handheld technologies are becoming more embedded, ubiquitous and networked, with enhanced capabilities for rich social interactions, context awareness, and connectivity. The ubiquity of mobile technologies has led to unprecedented changes in the provision of mobile museum resources, which are beginning to transform the experience of visiting museums. Mobile technologies and their uses within museum collections have until recently been explored primarily from a technical viewpoint, typically ignoring the impact these technologies can have on visitor learning and engagement ${ }^{5}$. Increasingly, museum professionals are moving beyond a focus on the technology to consider the implications on visitor experience and focusing on new ways of utilizing handheld technology for object interpretation and visitor engagement. However there is yet to be a body of sustained critical thinking about the meanings and theoretical implications of the transformation and possibilities provided by mobile technologies in museums.

In the past decade, there has been a growing interest in exploring how digital and communication technologies can be developed to offer visitors a more personalized museum experience $^{6}$, provide more flexible and tailored information, and to facilitate interaction and 
discussion between visitors. Many museums are utilising mobile technology to aid visitor orientation and wayfinding as well as to offer specific multimedia tours within the museum. The Tate Modern multimedia tours ${ }^{7}$ use location tracking for personalized content delivery, the handheld device includes background information, video and still images that gave additional context for the works on display, and the ability to listen to an expert talk about details of the art work. The British Museum has recently launched a multimedia guide that supports way finding and orientation without relying on location aware technology. ${ }^{8}$ The Exploratorium has undertaken numerous projects exploring mobile technology within the museum space 9 . The use of mobile technologies in museums has been focused around linear curatorial narratives, but there has been little incentive for visitors to create their own narratives. Only rarely have museum visitors been able to participate in narrative creation or sharing. Projects such as Bletchley Park Text ${ }^{10}$ encouraged museum visitors to construct narratives by sending text messages from specific exhibits; visitors could create a personalized web page which links their chosen topics in narrative threads. Culture Shock ${ }^{11}$ led by Tyne and Wear Museums utilizes digital storytelling to make museum collections more relevant to the lives of people living in the North East of England. The BBC's Capture Wales $^{12}$ project encouraged community co creation of narratives via a travelling multimedia facility and a number of narrative technique workshops. However these projects seem to hesitate in their approach to sharing individual narratives with other visitors within the museum.

In general, however, despite the growing interest in deploying mobile technology as interpretation devices in museums and galleries, and the substantial body of research concerned with visitor behavior, there is yet to be established a critical literacy for describing the functional link between the narrative experience and museum mobile technologies. There is preliminary evidence that handheld technology can increase engagement with museum collections $^{13}$ and with the physical museum surroundings ${ }^{14}$ as well as increase visitor confidence, motivation and involvement ${ }^{15}$. However, to date, no empirical studies of museums utilizing mobile technology have been undertaken to look specifically at visitor narrative construction.

The QRator project aims to stress the necessity of engaging visitors actively in the creation of their own interpretations of museum collections. Located within the emerging technical and cultural phenomenon known as 'The Internet of Things': the technical and cultural shift that is anticipated as society moves to a ubiquitous form of computing in which 
every device is 'on,' and connected in some way to the Internet. The project is based around technology developed at the Centre for Advanced Spatial Analysis, University College London (UCL) and is an extension of the "Tales of Things" project (http://www.talesofthings.com), which has developed a "method for cataloguing physical objects online which could make museums and galleries a more interactive experience"16 via means of two-dimensional barcodes, known as QRCodes. The use of barcodes allows objects to be scanned and information retrieved in a quick and easy manner. The introduction of QRCodes within QRator provides the opportunity to move the discussion of objects from the museum label onto users' mobile phones, allowing the creation of a sustainable, world leading model for two-way public interaction in museum spaces.

\section{The Grant Museum: Enhancing Interpretation}

UCL's Grant Museum of Zoology houses one of the country's oldest and most important natural history collections. It has a strong history as a teaching collection but also functions as a key gateway for the public to engage with academic issues in innovative ways. In 2003 the Grant Museum displays were reinterpreted as part of the Say It Again, Say It Differently $\operatorname{project}^{17}$, which was aimed at helping museums to refresh their displays. Reinterpretation resulted in bringing some sense of order to the Grant Museum; however, it was not possible to label every object in the dense museum displays. One of the goals for the project was to go beyond conveying facts about natural history to explore the many narrative threads of the objects in the museum. As Assistant Curator of the Grant Museum of Zoology, Jack Ashby, notes, "There is no centrally running theme through the museum- each specimen tells a different story, be it historical, mythological, museological, ecological or zoological" (Ibid).

Additionally the Grant Museum has been involved with a project with Collections $\operatorname{Link}^{18}$, a network for sharing knowledge about museums practice, called Revisiting Collections. Revisiting Collections explored methodologies for constructing narratives around objects and collections through working with focus groups. The resulting constructed narratives were made available in the museum through physical labels; the information was also attached to objects in collections databases. Focus groups and narrative workshops have limited scope for smaller museums, as it is time and resource consuming and there are problems associated with biases from soliciting responses to objects directly in such focussed sessions. The QRator project, through mobile devices, allows for 'more honest' input from visitors, albeit responses which are still solicited but less steered by staff representing museums. The context is still shaped and framed by the objects and questions chosen by 
museum staff, however, museum visitors have the freedom to say as little or as much as they may desire or nothing at all.

One of the main problems of interpreting objects through object labels is that labels have to be condensed and succinct so as not to overwhelm the museum visitors with walls of text. As an example, a label for an elephant specimen in a natural history museum could discuss the conservation movement, elephant poaching, ivory jewellery, traditional medicines, elephants as religious icons, elephant behaviour, extinction of mammoths, any one of the unique ways that elephants are adapted to their environment, the taxonomy of elephants, elephants as circus animals, elephants and memory, the evolution of elephants, elephants as a mode of transport, elephants and war, elephant folklore, elephant jokes, or elephants in popular culture. In a typical museum label it will only be possible to construct a sentence on one or two of these themes. A favourite example at the Grant Museum is a label for a flying lemur specimen which only serves to tell the visitor that a flying lemur is not a lemur and furthermore it cannot fly. Utilising mobile media within the Grant Museum allows for greater depth of information as well as a greater flexibility in the kinds of content and information that can be linked to any particular object, including video, audio, images and further links to other web content. Because visitors can opt to explore objects further, those who want to find out more can locate that information without overwhelming all visitors. Conventional museum labels only allow for one way communication: as a consequence there is insufficient space for cryptic labels or those that ask a question of a visitor to include explanations or allow a visitor to answer. The only way for a visitor to engage in this way would be to engage with museum staff. The QRator technology, however, allows for visitors to leave their own thoughts and comments on objects, which can be challenging to do seamlessly within museum spaces.

\section{QR Codes and Constructing Collaborative Narratives}

Visitor meaning making has been a dynamic research theme in museum studies for over a decade $^{19}$. Both constructivist learning theory ${ }^{20}$ and hermeneutic philosophy tell us that narrative is central to meaning making and individuals actively construct meaning for themselves using their existing knowledge in interpreting new experiences ${ }^{21}$. The importance of narrative, and particularly narrative with multiple voices ${ }^{22}$, has become an influential argument for constructivist interpretation in museums and should replace the traditional authoritative knowledge-dissemination as the iconic mode for museums. Previous studies note the importance of visitor expectations in framing museum experiences ${ }^{23}$. Doering and 
Pekarik $^{24}$ state that visitors bring their own 'entrance narratives' to museums providing a personal storyline informing their expectations and overall experience. However, narratives and personal stories have had a much less prominent role in natural history or science museums, where the dominant mode of interpretation is a single-voiced authoritative explanation. Even the relatively uncomplicated interpretation of objects through object biography rather than subject or personality biography remains comparatively unexplored in museums and even more so in scientific museums ${ }^{25}$. Mobile technology can provide a platform to help to discover these internal stories and entrance narratives and share them with a wider audience, providing a broader more personal interpretation of museum collections. We believe that through utilising the strengths of digital storytelling (its ability to allow individuals to reflect and create their own meaning ${ }^{26}$ ), as well as being able to collect personal narratives of museums experience, the use of mobile technologies in the Grant Museum can also contribute to the creation of interpretative communities ${ }^{27}$ and the sharing of multiple narratives.

The QRator project offers opportunities for visitors to consume and create digital content, empowering members of the public to become the "curators." The Grant Museum is taking a proactive role in developing new audience driven narratives centered on the museum's collections. The project develops a custom UCL Museums iPhone, and Android application which is available free of charge from the iTunes store and Android market place. QR codes for museum objects, and in some instances whole displays have been created, linked to an online database allowing the public to view "curated" information, and, most notably, to send back their own interpretation and views via their own mobile phone. Unique in the UCL technology is the ability to "write" back to the QR codes. This allows member of the pubic to type in their thoughts and interpretation of the object and click "send." Similar in nature to sending a text message, the system will enable the Grant Museum to become a true forum for academic-public debate, using low cost, readily available technology, enabling the public to collaborate and discuss object interpretation with museum curators and academic researchers. Visitors' narratives subsequently become part of the museum objects' history and ultimately the display itself, via the interactive label system which will allow the display of comments and information directly next to the artifacts. This shift in focus from content delivery to narrative construction can be suggested to be reflecting a societal shift in digital media ${ }^{28}$, and the internet in general, from static centralized control to user generated content and personalized learning. Personal narratives, interactive dialogues and multiple 
interpretations saturate the internet and museums need to adapt to visitor expectations to fully enable rich meaning making experiences to take place.

The QRator project utilizes user-centered design principles, by explicitly and actively including users in the development process from the beginning. When studying the users of digital technologies it can be argued that use in context is an ideal method as there is a need to understand the real circumstances in which technology is used so that any problems can be found $^{29}$. Thus to produce mobile technology which is most useful in a museum context there is a need to understand the circumstances in which it will function. The project takes concepts of users, narrative, space, object, location, and as well as the appropriate means of mediating the museum experience via a handheld mobile device into account. However there are issues to take into consideration. If mobile engagement with museum interpretation can occur anywhere, then how can we track and record the learning and narrative creation processes? If the learning and meaning making is interwoven with other everyday activities, then how can we tell when it occurs? If visitor meaning making is self-determined and selforganized, then how can we measure engagement outcomes? These are difficult questions with no simple answers, yet it is essential to address them if we are to provide evidence of the effectiveness of mobile media for visitor narrative construction and meaning making.

In order to address these questions, a small pilot study was undertaken to focus on the use of the mobile technology in context. Nine objects were chosen for a pilot project, utilising Tales of Things ${ }^{30}$, the technology behind the QRator system, Tales of Things explores the provenance of old objects and how the memoires associated with these objects may impact social memories in the community. A case in point is the take up of the system by $\mathrm{Oxfam}^{31}$ to explore and add value to donated goods within the charity sector. The history of second household objects is often undocumented, tied up in personal and family history. Yet when objects are donated to a high street charity organisation, these retail outlets become temporary museums. In the Oxfam context, the barcode label becomes the communicator of history with the ability to record new chapters in an objects life direct via a link to a smart phone. In short, Tales of Things is a bespoke technology allowing everyday objects to 'talk' via the Internet of Things. QRator, takes this a step further in a more traditional museum context whereby the objects represent different, interesting, facets of museology. The objects represent different, interesting, facets of museology. These included the museum's spotlight specimens: objects considered valuable in terms of their craftsmanship, history and rarity, objects that either were not on display at all, or those that challenge the term "object" such as 
the whole of the museum or transient features such as a display case for temporary exhibitions whose contents change periodically. Furthermore, some of these "objects" would not normally be labelled, so adding them to the Tales of Things library provides a novel way to access these otherwise publicly inaccessible objects.

The objects were deliberately chosen to explore aspects of 'objects' and the concept of objects that cannot adequately be highlighted by traditional static museum hermeneutics. Museum labels often have a very strict word limit and cannot convey more than a single aspect, fact or story about an object. It is important to note, however, that these narratives can be (and are) explored in a guided tour of the museum but that it is not possible for every visitor to receive a personal tour of the collection from an expert guide who knows the objects well. Many of these test objects were chosen to relay narratives as a proxy to staff lead tours with the added advantage of the capacity to record feedback and ask questions of visitors. Other objects were chosen because they are otherwise uninterpretable either because they aren't objects in normal senses or because the narratives involved do not fit within the over arching narratives within the museum space. In the Grant Museum the grander narrative is the evolutionary history of animal life on Earth. Discrete QR codes allow meta-narratives and cryptic narratives that do not interfere with the main narrative theme of the museum.

The three legged skeleton of a quagga, a cast of Archaeopteryx lithographica and the articulated skeleton of an anaconda were given QR codes to interpret multiple narratives of each specimen. The labels for these objects examines them within the context of the taxonomic display. In the museum the specimens are representing the biological species and subspecies to which they are members. However, each of these specimens is also of interest outside of a strictly biological narrative framework. The quagga skeleton is arguably the rarest skeleton in the world and is mysteriously missing a leg and a shoulder blade. The museum has historical photographs of the anaconda skeleton being prepared from a dead animal to an articulated skeleton. Archaeopteryx is one of the most important specimens in evolutionary biology but the Grant Museum specimen is only a cast and is surrounded by a host of apocrhyphal historical stories.

Other specimens were labelled to allow a meta analysis of the way in which museums work. A red deer skull had been labelled as "Bambi's Dad" by the museum conservator and Tales of Things was used to highlight potential contentious interpretation in museums, 
questioning whether there is a place for humour in museums or is such labelling disrespectful? Another specimen, unidentifable and sealed in wax was put on display and labelled to emphasize the elements of detective work inherent in working in museums as well as difficulties associated with the ownership of cultural heritage and displaying uncertainty. Tales for Archaeopteryx, a fluid preserved specimen of the extinct marsupial thylacine and a ninteenth century Blaschka glass model of a snail questioned ideas behind the importance of museum objects around problematic concepts such as authenticity, real and fake objects, the fallacy of empirically identifying organisms and the sentimental and financial value of historical associations.

Lastly, the museum itself was tagged an given a tale as an object in order to explore what is meant exactly by "the museum." "The Grant Museum" itself can be used to describe a series of geographical locations, including the museum, storerooms, and offices, but these locations can be changed. When objects were removed from the space in UCL's Darwin building at what point did it stop being "The Grant Museum" and what happened to "The Grant Museum" whilst objects were in storage? Did the room cease to be the Grant Museum when the last specimen left, when it closed to the public or when the sign was taken down? The term can also be used to describe a collection of 68,000 objects. For legal purposes the Grant Museum means something very different and in other senses the Grant Museum is more of a brand or identity. Labelling the museum as 'an object' in a way that would be impossible to do with traditional labels was intended to provoke thoughts about how we define objects as well as enabling visitors to add tales from within the object itself.

It is possible to discover how visitors interact with, and create narratives from, the museum objects by analysing the frequency of codes scanned and to study visitor feedback in the form of tales, further links, and other information that visitors leave on the Tales of Things site. Although this does not quite establish a dialogue with museum visitors it does allow museum curators to ask questions of the visitor or use contentious objects to provoke a response. The QRator project found that utilising contentious objects and asking provoking questions encouraged visitor's participation in collaborative narrative creation. In this way mobile technology has the capability to support visitors' meaning making by framing and focusing their activities and interactions. The objects were available to be scanned in situ for a period of two weeks, the trial period coincided almost exactly with the relocation of the 
Grant Museum of Zoology allowing only a two-week period before the museum was closed to the public.. In total the 9 Grant Museum object's added to the Tales of Things site had been viewed online 1374 times (figure 1) and a total of 34 scans occurred (see figure 2).

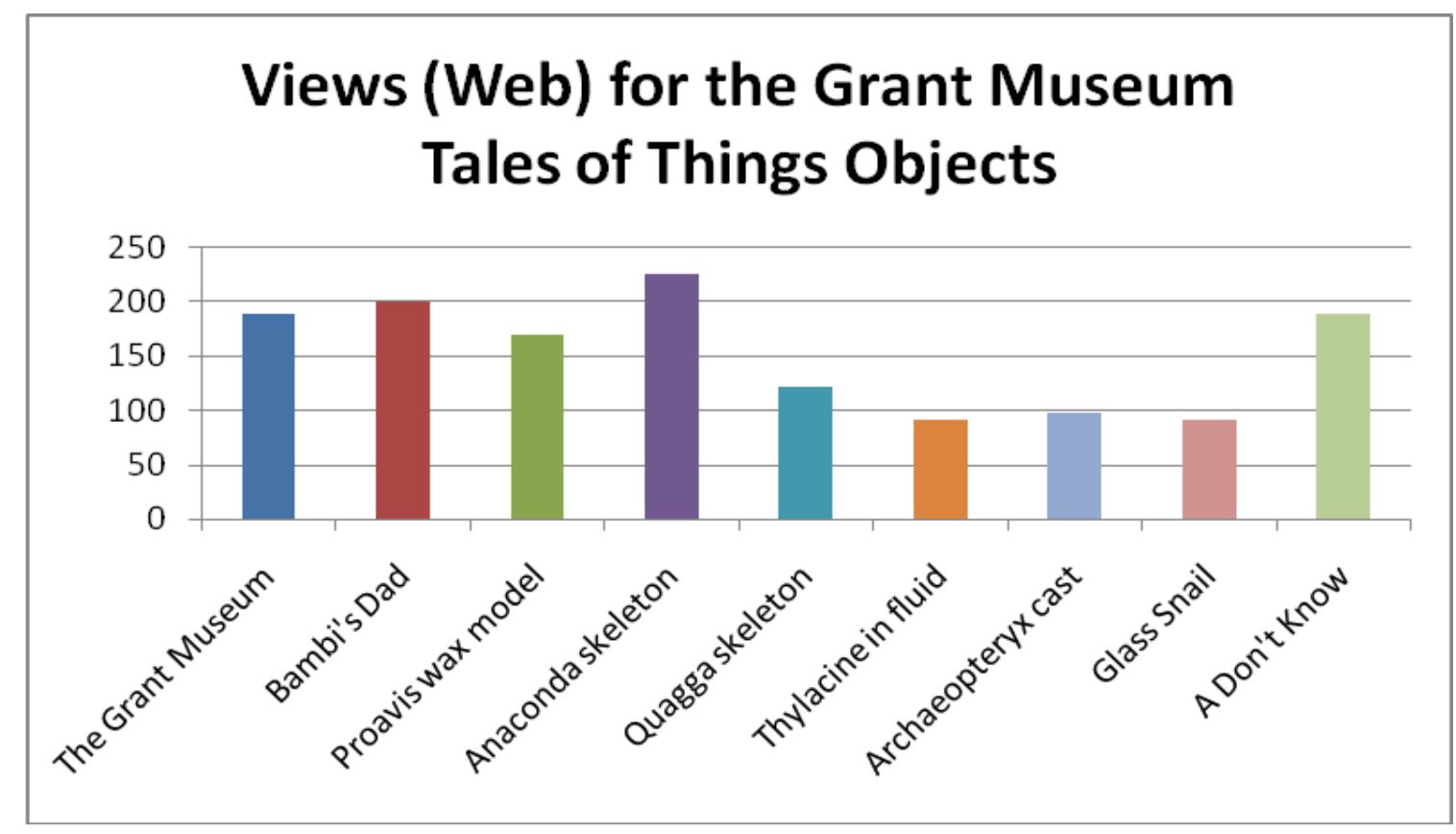

Figure 1: Graph showing the online view statistics for the Grant Museum Tales of Things objects

Once scanned visitors developed the narrative of the objects by adding their own interpretations. This reshaping of audience involvement and narrative construction centred on museum objects facilitates creative, independent analysis, promoting a personal connection with museum exhibition subject matter that has been suggested to be unparalleled in more traditional and passive approaches to museum interpretation ${ }^{32}$. Visitors to the museum felt the QR codes provided a more personalised experience compared to gallery books because they could see information more easily and crucially because they could use it while walking around the museum. Several visitors stated that using QR codes in the gallery enhanced their museum experience and made them spend more time in the museum. One interesting observation is that without the additional information provided by the QR codes and additional visitor narratives some of the specimens would have been difficult to understand and appreciate ${ }^{33}$.

\begin{tabular}{|l|l|l|l|l|l|l|l|l|l|}
\hline Object & $\begin{array}{l}\text { The Grant } \\
\text { Museum }\end{array}$ & $\begin{array}{l}\text { Bambi's } \\
\text { Dad }\end{array}$ & $\begin{array}{l}\text { Proavis } \\
\text { wax } \\
\text { model }\end{array}$ & $\begin{array}{l}\text { Anaconda } \\
\text { skeleton }\end{array}$ & $\begin{array}{l}\text { Quagga } \\
\text { skeleton }\end{array}$ & $\begin{array}{l}\text { Thylacine } \\
\text { in fluid }\end{array}$ & $\begin{array}{l}\text { Archaeopt } \\
\text { eryx cast }\end{array}$ & $\begin{array}{l}\text { Glass } \\
\text { Snail }\end{array}$ & $\begin{array}{l}\text { A Don't } \\
\text { Know }\end{array}$ \\
\hline $\begin{array}{l}\text { Views } \\
\text { (Web) }\end{array}$ & 189 & 200 & 170 & 225 & 121 & 92 & 97 & 92 & 188 \\
\hline
\end{tabular}




\begin{tabular}{|l|l|l|l|l|l|l|l|l|l|}
\hline Tales & 3 & 1 & 1 & 3 & 2 & 2 & 1 & 1 & 1 \\
\hline Scans & 7 & 4 & 0 & 9 & 0 & 2 & 5 & 2 & 5 \\
\hline
\end{tabular}

Figure 2: Number of Interactions with the Grant Museum Tales of Things Objects

From these the preliminary findings of a small pilot, it was felt there was satisfactory user engagement to develop this concept further by utilising QR code technology with situated iPads' in the museum space itself, providing a platform for narrative creation. The Grant Museum now hosts iPads' containing 'Current Questions' for visitors to engage in, enabling the museum to be a place not simply for a passive experience but for conversation. Each object on Tales of Things has a unique identifier, which the iPad uses to access the objects information, QR code and subsequent narratives left by visitors from the server. The QRator application is therefore a viewer for the Tales of Things website allowing visitors to interact directly with existing narratives. Anecdotal evidence suggests that this stage of the QRator project, has produced over 900 individual visitor narratives, focusing on the personal interpretation of the Grant museum's collections. It is possible to suggest that this further extension of the QRator project denotes that visitor narrative construction via mobile media is making a valuable contribution to enhancing the museum experience. Further research is underway to with the aim of developing our understanding of how mobile devices can expand and augment public engagement inside Natural History museum spaces. It is not sufficient that mobile technology enhance visitor narrative construction and the overall museum experience; "it needs to be demonstrated that these new technologies enhance museum experience" ${ }^{\text {34 }}$. We believe that by the end of the QRator project we will be able to demonstrate that mobile technology can impact upon visitors' experience of museums and their personal narrative creation.

There has been an enormous impact of mobile technology on museums. This is mainly due to the great potential that such solutions offer to museums and their visitors. Advantages include variety of interpretation, engagement of visitors, outreach to new audiences, support for orientation, and flexibility with content distribution ${ }^{35}$. Mobile media resources have gone from being one technology, named audio guides, providing structured linear narratives, to become quite diverse in functionality offering a range of personalized content. While interactive mobile technologies are becoming commonplace in museums the way narrative experiences are designed has changed very little. For this to evolve Russo and Watkins suggest a two way interaction New Literacy framework must be developed. ${ }^{36}$ Museums must 
look at how to deliver mobile media resources which are visitor focused and provide opportunities for consuming and creating content, as well as for individual learning. The QRator project is developing a framework by reshaping narrative construction by opening up museum interpretation to visitors.

The growth of research and development of mobile technology to support learning ${ }^{37}$ has proved particularly important to museums for creating digital media frameworks. Research on visitor learning in museums suggests that active interaction with museum content promotes understanding, engagement, and recollection of objects and exhibitions ${ }^{38}$. The concept of meaning making provides a useful approach to understanding visitor learning experiences: many museums now accept the "constructivist" view that knowledge is actively produced by a visitor and focus not on individual learning but what the museum contributes to existing knowledge and experience. The paradigm highlights visitors' active role in creating meaning of a museum experience. Each visitor has their own agenda, identity, motivation, and interests and will approach the museum with different perspectives. As a result, visitors find their own personal significance within museums. This growing emphasis on the interactional and informal nature of learning in museums provides the perfect opportunity to showcase mobile interactive technologies as important resources for engaging visitors in exhibits and more generally in museums as a whole ${ }^{39}$. We believe that mobile technologies can be used to build more engaging visitor experiences by facilitating interactivity and co construction of narrative directly: this is due to their personal, portable and networked nature. By enabling museum visitors to be co-constructors of narratives, museums can encourage a deeper connection with museum objects, and enhance meaningmaking activities that define the constructivist approach. ${ }^{40}$ In this way mobile technology can mediate visitors meaning making.

Falk and Dierking's contextual model of learning ${ }^{41}$ is a compelling framework to utilise when designing and developing museum mobile media for visitor narrative construction and meaning making. The contextual model of learning draws from constructivist, cognitive and social culture theories. The key feature is the emphasis on context; personal, sociocultural and physical. In order to deliver narrative rich mobile media museums need to be aware of the personal, sociocultural and physical context within which to enable to make meaning from their experience. Mobile technologies have the capability to support visitors' meaning making by framing and focusing their activities and interactions, this represents an important 
and powerful way that museums can offer choice and individualized narrative opportunities to visitors.

\section{Conclusion}

This chapter has aimed to introduce the concept of mobile technology in museums as a way to create narratives of museums' experience and then share multiple narratives with an interpretive community. By offering opportunities for visitors to consume and create digital content, museums can take a proactive role in developing new narratives around museum collections, enabling direct experience of content production. This new co-creation of narratives has effective cultural outcomes; utilising mobile media has enabled the Grant Museum to highlight visitors' active role in creating meaning of their own museum experience. Each visitor has their own agenda, identity, motivation, and interests and will approach the museum with different perspectives. As a result, visitors find their own personal significance within museums and are now able to share it with other visitors. Visitors are empowered to create their own 'digital stories', narratives constructed from their own interpretation of museum collections. However museum mobile technology cannot be used in isolation. These tools are important, but of equal importance is their relationship to other forms of museum interpretation, and of course, the visitors themselves. It is vital to incorporate the views and previous experience of visitors when undertaking collaborative content and mobile technology development in museums. This research reinforces how complex museum experience is as well as the difficulties of designing for narrative construction in a museum setting. This chapter offers insights into why and in what ways mobile media, specifically QR codes and digital collaboration interpretation technology, have the potential to enhance the personal and community narratives and meaning making of museum experiences. Nevertheless, it is not until a strong research base has been developed that we will begin to truly understand the use of mobile technology as narrative tools and to fully validate their value to museums and their visitors.

1 R.R. Archibald, Touching on the Past. Missouri Historical Society, St. Louis, Missouri, (2006). http://web.mac.com/bandelli/2020/References_files/Archibald_Keynote text.pdf (accessed 27th January 2011)

${ }^{2}$ M. Adams., J, Luke and T. Moussouri, Interactivity: Moving Beyond Terminology. Curator: The Museum Journal, 47: (2004) 155-170 and see also J.H. Falk, and L. Dierking. Learning from Museums. Visitor Experiences and the Making of Meaning. Walnut Creek, Lanham, New York and Oxford, Alta Mira Press, 2000 
${ }^{3}$ J. H. Falk et al. A multi-institutional study of exhibition interactives in science centers and museums. Unpublished evaluation report. Annapolis, MD: Institute for Learning Innovation, (2002) see also G. Black, The Engaging museum: Developing museums for visitor involvement. New York: Routledge, 2005

${ }^{4}$ M. Fisher, and B.A. Twiss-Garrity, "Remixing Exhibits: Constructing Participatory Narratives With On-Line Tools To Augment Museum Experiences" (2007). In Trant, J., Bearman, D. (eds). Museums and the Web 2007: Proceedings. Toronto: Archives \& Museum Informatics. Available from: http://www.archimuse.com/mw2007/papers/fisher/fisher.html (accessed on 19th October 2010)

${ }^{5}$ F. Cameron, Digital Futures I: Museum Collections, Digital Technologies, and the Cultural Construction of Knowledge. Curator, 46, no 3 (2003): 325-40

${ }^{6}$ G. Gay, and A. Spinazze, Handscape: exploring potential use scenarios for mobile computing in museums, Cultivate Interactive, $8,(2002)$

${ }^{7}$ N. Proctor, J. Burton, and C. Tellis, "The State of the Art in Museums Handhelds in 2003" (2003). In Proceedings of Museums and the Web 2003. Toronto: Archives \& Museums Informatics,. http://www.archimuse.com/mw2003/papers/proctor/proctor.html (access on 20th January 2011)

${ }^{8}$ S. Filippini-Fantoni et al., "Mobile devices for orientation and way finding: the case of the British Museum multimedia guide" (2011). In J. Trant and D. Bearman (eds). Museums and the Web 2011: Proceedings. Toronto: Archives \& Museum Informatics. Published March 31, 2011. Consulted http://conference.archimuse.com/mw2011/papers/mobile_devices_for_wayfinding

${ }^{9}$ S. Hsi. "The Electronic Guidebook: A Study of User Experiences Mediated by Nomadic Web Content in a Museum Setting." (2003) Journal of Computer-Assisted Learning, vol. 19, no 3 (September): 308-319.

${ }^{10}$ P. Mulholland, T. Collins, and Zdrahal, Zdenek. "Bletchley Park text: using mobile and semantic web technologies to support the post-visit use of online museum resources" (2005) In Journal of Interactive Media in Education, 24 Special Issue: Portable Learning - Experiences with Mobile Devices

${ }^{11}$ Culture Shock, http://www.cultureshock.org.uk (accessed on $6{ }^{\text {th }}$ May 2011)

${ }^{12}$ BBC “Capture Wales," http://www.bbc.co.uk/wales/arts/yourvideo/queries/capturewales.shtml (accessed 19th March 2011)

${ }^{13}$ See Proctor, Burton and Tellis 2003; Hsi 2003

${ }^{14}$ L. Naismith, M. Sharples, \& J. Ting, Evaluation of CAERUS: a Context Aware Mobile Guide. In van der Merwe, H. \& Brown, T. (eds.) Proceedings of mLearn 2005 - Mobile technology: The future of learning in your hands, Cape Town, South Africa, 2005: 112-115.

${ }^{15}$ E. Burkett, Using handheld computers to stimulate critical studies in A-Level art, Becta. (2005) http://www.evaluation.icttestbed.org.uk/learning/research/secondary/interest/collaboration (accessed 20th January 2011)

${ }^{16}$ J. Giles, Barcodes help objects tell their stories. New Scientist, $17^{\text {th }}$ April, 2010

17 Grey,A. , Gardom, T., and Booth, C. . Museums Libraries and Archives London, 2006 http://www.mla.gov.uk/what/programmes/renaissance/regions/london/News_and_Resources/ /media/London/Fi les/2009/Publications/SayingitdifferentlyAW.ashx (Accessed on 31st January 2011)

${ }^{18}$ Collections Link http://collectionslink.org.uk (Accessed on 31st January 2011) 
${ }^{19}$ See L. H. Silverman, Visitor Meaning-Making in Museums for a New Age. Curator: The Museum Journal, 38: (1995) 161-170 and E. Hooper-Greenhill, Museums and the Interpretation of Visual Culture, Routledge, London, 2000

${ }^{20}$ G. Hein, The constructivist museum. Journal of Education in Museums, 15, (1995) 1-10.

${ }^{21}$ See J. Bruner, "Frames for thinking: Ways of making meaning.” In D. R. Olson \& N. Torrance (Eds.), Modes of thought: Explorations in culture and cognition. New York: Cambridge University Press. 1996: 93-105; R.C. Shank. Tell me a story. Evanston, IL: Northwestern University Press, 1990; K. Egan, "Narrative and learning: A voyage of implications." In H. McEwan \& K. Egan (Eds). Narrative in teaching, learning, and research. NY: Teachers College Press, 1995: 116-125 and H. Hooper-Greenhill, and T. Moussouri, Making Meaning in Art Museums 1: Visitors' Interpretive Strategies at Wolverhampton Art Gallery, Leicester: RCMG (Research Centre for Museums and Galleries), 2001

${ }^{22}$ L. Roberts, From knowledge to narrative. Washington, DC: Smithsonian Institution, 1997

${ }^{23}$ See J. H. Falk, et al. "The effect of visitors' agendas on museum learning." Curator, 41(2), (1998)106-120; Falk, J.H. (2006) "The Impact of Visit Motivation on Learning: Using Identity as a Construct to Understand the Visitor Experience," Curator 49(2): 151-66; G. Leinhardt, and K. Crowley, Museum learning as conversational elaboration: A proposal to capture, code and analyze museum talk. Museum Learning Collaborative Technical Report MLC-01(1998)

${ }^{24}$ Z.D. Doering, and A.J. Pekakirk, Questioning the entrance narrative. Journal of Museum Education 21(3): (1996) 20-22.

${ }^{25}$ S.J.M.M. Alberti, “Objects and the Museum.” Isis, 96, (2005): 559-571

${ }^{26}$ See G.A. Hull, and M.L. Katz, "Crafting an Agentive Self: Case Studies of Digital Storytelling." Research in the Teaching of English 41, 1, (2006): 43-81; K. Walker, "Narrative and Mobile Learning in Practice and Theory" II Kaleidoscope workshop on Narrative Learning Environments, Palermo, Italy, 26-28 June 2006 and S. Ruston, J. and Stein, "Narrtaive and Mobile Media." MiT4: The Work of Stories. 2005 http://web.mit.edu/comm-forum/mit4/papers/Ruston\%20Stein.pdf (accessed on $27^{\text {th }}$ January 2011)

${ }^{27}$ S. Fish, Is there a text in this class? The authority of interpretive communities, Harvard University Press, Cambridge MA and London, 1980

${ }^{28}$ K. Walker, "Structuring Visitor Participation." in Digital Technologies and the Museum Experience: Handheld Guides and Other Media, edited by Loïc Tallon and Kevin Walker, AltaMira Press, August 2008

${ }^{29}$ M. Terras, C. Warwick, and C. Ross, "Building Useful Virtual Research Environments: The Need for Usedled Design." In P. Dale, J. Bears, and M. Holland (eds). University Libraries and Digital Learning Environments. Ashgate, Surry, Burlington, (2011): 151-167

${ }^{30}$ Tales of Things http://www.talesofthings.com

${ }^{31}$ R. Barthel, et al. "Tales of Things - The Internet of 'Old' Things: Collecting Stories of Objects, Places and Spaces." in Proceedings of the Second International Conference on the Internet of Things 2010 (IoT 2010), Tokyo, Japan. IEEE Digital Library. (2010)

${ }^{32}$ L. H. Silverman, "Visitor Meaning-Making in Museums for a New Age." Curator: The Museum Journal, 38 : (1995) 161-170; L. Roberts, From knowledge to narrative. Washington, DC: Smithsonian Institution, 1997 ; E. Hooper-Greenhill, Museums and the Interpretation of Visual Culture, Routledge, London, 2000, and M. Fisher, and B.A. Twiss-Garrity, Remixing Exhibits: Constructing Participatory Narratives With On-Line Tools To Augment Museum Experiences" (2007). In J. Trant, D, Bearman, (eds). Museums and the Web 2007: 


Proceedings. Toronto: Archives \& Museum Informatics. $\quad$ Available from:
http://www.archimuse.com/mw2007/papers/fisher/fisher.html (accessed on 19th October 2010)

${ }^{33}$ Ross, C. Unpublished research Report and (2010). Haywood, N.Unpublished research Report: The Future of the Ancient World. (2011)

${ }^{34}$ Falk, J.H., and Dierking, L.D. " Enhancing Visitor Interaction and Learning with Mobile Technologies" in L.Tallon and K. Walker. (eds) Digital Technologies and the Museum Experience: Handheld Guides and Other Media, AltaMira Press, August 2008 (p28)

${ }^{35}$ S. Filippini Fantoni and J. Bowen, "Mobile Multimedia: Reflections from Ten Years of Practice" in L.Tallon and K. Walker. (eds) Digital Technologies and the Museum Experience: Handheld Guides and Other Media, AltaMira Press, August, 2008

${ }^{36}$ A. Russo, and J. Watkins, "Digital Cultural Communication: Audience and Remediation" in F. Cameron and S. Kenderdine (eds) Theorizing Digital Cultural Heritage Cambridge, Mass., MIT Press, 2005

${ }^{37}$ J. Taylor, et al, Towards a task model for mobile learning: a dialectical approach. (2006) Available from http://kn.open.ac.uk/public/document.cfm?docid=5374 (accessed on $5^{\text {th }}$ May 2011)

${ }^{38}$ See; S. Allen, "Designs for Learning: Studying Science Museum Exhibits That Do More Than Entertain." Exploratorium, San Francisco, 2004. http://learningspaces2008.pbworks.com/f/Allen_Exploratorium.pdf (accessed on 20th January 2011) and J.H. Falk, and L. Dierking. Learning from Museums. Visitor Experiences and the Making of Meaning. Walnut Creek, Lanham, New York and Oxford, Alta Mira Press, 2000

39 See S. Thomas, and A. Mintz, Eds. The Virtual and the Real: Media in the Museum. Washington, DC, American Association of Museums, 1998.; P. Marty, and K. Burton Jones, Museum Informatics: People, Information, and Technology in Museums. Routledge, New York, 2007; C. Heath, and D. vom Lehn. Interactivity and Collaboration: new forms of participation in museums, galleries and science centres. In Museums in a Digital Age, ed. R. Parry, Abingdon: Routledge, 2010, 266-280

${ }^{40}$ B. Mott, et al. "Towards Narrative-Centered Learning Environments." Working Notes of the 1999 AAAI Fall Symposium on Narrative Intelligence, pp. 78-82, Cape Cod, MA, November 1999. (p.80)

41 J.H. Falk, and L.D. Dierking. "Enhancing Vistor Interaction and Learning with Mobile Technologies in L.Tallon and K. Walker. (eds) Digital Technologies and the Museum Experience: Handheld Guides and Other Media, AltaMira Press, August, 2008

\section{Bibliography}

Adams, M., Luke, J. and Moussouri, T. "Interactivity: Moving Beyond Terminology." Curator: The Museum Journal, 47: (2004) 155-170

Alberti, S.J.M.M. “Objects and the Museum.” Isis, 96, 2005: 559-571

Allen, S. "Designs for Learning: Studying Science Museum Exhibits That Do More Than Entertain." Exploratorium, San Francisco, 2004. http://learningspaces2008.pbworks.com/f/Allen_Exploratorium.pdf (accessed on 20th January 2011)

Archibald, R.R. Touching on the Past. Missouri Historical Society, St. Louis, Missouri, 2006. http://web.mac.com/bandelli/2020/References_files/Archibald_Keynote_text.pdf (accessed 27th January 2011) 
Barthel, R., Hudson-Smith, A., De Jode, M., Blundell, B. "Tales of Things - The Internet of 'Old' Things: Collecting Stories of Objects, Places and Spaces." To appear in Proceedings of the Second International Conference on the Internet of Things 2010 (IoT 2010), Tokyo, Japan. IEEE Digital Library. 2010

Black, G. The Engaging museum: Developing museums for visitor involvement. New York: Routledge, 2005

Bruner, J. "Frames for thinking: Ways of making meaning." In D. R. Olson \& N. Torrance (Eds.), Modes of thought: Explorations in culture and cognition.New York: Cambridge University Press. 1996: 93-105

Burkett, E. Using handheld computers to stimulate critical studies in A-Level art, Becta. 2005http://www.evaluation.icttestbed.org.uk/learning/research/secondary/interest/collaboration (accessed 20th January 2011)

Cameron, F. "Digital Futures I: Museum Collections, Digital Technologies, and the Cultural Construction of Knowledge." Curator, 46(3), (2003): 325-40

Doering, Z.D. and Pekakirk, A.J. "Questioning the entrance narrative." Journal of Museum Education 21(3): (1996) 20-22.

Egan, K. "Narrative and learning: A voyage of implications." In H. McEwan \& K. Egan (Eds). Narrative in teaching, learning, and research. NY: Teachers College Press, 1995: 116-125

Falk, J. H., Cohen Jones, M., Dierking, L. D., Heimlich, J., Scott, C., and Rennie, L. A multi-institutional study of exhibition interactives in science centers and museums. Unpublished evaluation report. Annapolis, MD: Institute for Learning Innovation, 2002

Falk, J. H., Moussouri, T., \& Coulson, D. “The effect of visitors' agendas on museum learning.” Curator, 41(2), (1998)106-120;

Falk, J., and L. Dierking. Learning from Museums. Visitor Experiences and the Making of Meaning. Walnut Creek, Lanham, New York and Oxford, Alta Mira Press, 2000

Falk, J.H. "The Impact of Visit Motivation on Learning: Using Identity as a Construct to Understand the Visitor Experience," Curator 49(2): (2006)151-66

Falk, J.H., and Dierking, L.D. "Enhancing Vistor Interaction and Learning with Mobile Technologies" in Digital Technologies and the Museum Experience: Handheld Guides and Other Media, edited by L.Tallon and K. Walker, AltaMira Press, August 2008 (p28)

Filippini-Fantoni, S., McDaid, S., and Cock, M. "Mobile devices for orientation and way finding: the case of the British Museum multimedia guide." In Museums and the Web 2011: Proceedings. Toronto: Archives \& Museum Informatics, edited by J. Trant and D. Bearman. (2011).http://conference.archimuse.com/mw2011/papers/mobile devices for_wayfinding (accessed on 27 $7^{\text {th }}$ April 2011)

Fish, S. Is there a text in this class? The authority of interpretive communities, Harvard University Press, Cambridge MA and London, 1980

Fisher, M. and Twiss-Garrity., B.A. "Remixing Exhibits: Constructing Participatory Narratives With On-Line Tools To Augment Museum Experiences" In Museums and the Web 2011: Proceedings. Toronto: Archives \& Museum Informatics, edited by J. Trant and D. Bearman. (2007). http://www.archimuse.com/mw2007/papers/fisher/fisher.html (accessed on 19th October 2010)

Gay, G., and Spinazze, A. "Handscape: exploring potential use scenarios for mobile computing in museums,"Cultivate Interactive, 8,2002 
Giles, J. "Barcodes help objects tell their stories.” New Scientist, 17 April, 2010

Grey,A. , Gardom, T., and Booth, C. Museums Libraries and Archives London, 2006 http://www.mla.gov.uk/what/programmes/renaissance/regions/london/News and_Resources/ /media/London/Fi les/2009/Publications/SayingitdifferentlyAW.ashx (Accessed on 31st January 2011)

Heath, C. and D. vom Lehn. "Interactivity and Collaboration: new forms of participation in museums, galleries and science centres. In R. Parry (ed) Museums in a Digital Age, Abingdon: Routledge, 2010, 266-280

Hein, G. “The constructivist museum.” Journal of Education in Museums, 15, 1995: 1-10.

Hooper-Greenhill, E. Museums and the Interpretation of Visual Culture, Routledge, London, 2000

Hooper-Greenhill, H. and Moussouri, T. Making Meaning in Art Museums 1: Visitors' Interpretive Strategies at Wolverhampton Art Gallery, Leicester: RCMG (Research Centre for Museums and Galleries), 2001

Hsi.S, "The Electronic Guidebook: A Study of User Experiences Mediated by Nomadic Web Content in a Museum Setting." Journal of Computer-Assisted Learning, vol. 19, no 3 (September): (2003)308-319.

Hull, G.A. and Katz, M.L. "Crafting an Agentive Self: Case Studies of Digital Storytelling." Research in the Teaching of English 41, 1, (2006): 43-81

Leinhardt, G. \& Crowley, K. Museum learning as conversational elaboration: A proposal to capture, code and analyze museum talk. Museum Learning Collaborative Technical Report MLC-0, 1998

Marty, P. and K. Burton Jones, Museum Informatics: People, Information, and Technology in Museums. Routledge, New York, 2007

Mott, B., Callaway, C. Zettlemoyer, L., Lee, S. and Lester, J. "Towards Narrative-Centered Learning Environments." Working Notes of the 1999 AAAI Fall Symposium on Narrative Intelligence, Cape Cod, MA, November 1999: 80

Mulholland, Paul; Collins, Trevor and Zdrahal, Zdenek, "Bletchley Park text: using mobile and semantic web technologies to support the post-visit use of online museum resources." Journal of Interactive Media in Education, 24 Special Issue: Portable Learning - Experiences with Mobile Devices 2005.

Naismith, L., Sharples, M. \& Ting, J. "Evaluation of CAERUS: a Context Aware Mobile Guide." In Proceedings of mLearn 2005 - Mobile technology: The future of learning in your hands, Cape Town, South Africa, edited by van der Merwe, H. \& Brown, T. (2005): 112-115.

Proctor, N., Burton, J., and Tellis, C. "The State of the Art in Museums Handhelds in 2003." In Proceedings of Museums and the Web 2003. Toronto: Archives \& Museums Informatics, 2003. http://www.archimuse.com/mw2003/papers/proctor/proctor.html (access on 20th January 2011)

Roberts, L. From knowledge to narrative. Washington, DC: Smithsonian Institution, 1997

Ross, C. Unpublished research Report, 2010

Haywood, N. Unpublished research Report: The Future of the Ancient World. 2011

Russo, A. and Watkins, J. 2005, "Digital Cultural Communication: Audience and Remediation" Theorizing Digital Cultural Heritage edited by F. Cameron and S. Kenderdine Cambridge, Mass., MIT Press, 2005

Ruston, S., and Stein, J. Narrtaive and Mobile Media. MiT4: The Work of Stories. 2005 http://web.mit.edu/comm-forum/mit4/papers/Ruston\%20Stein.pdf (accessed on 27 January 2011) 
Shank, R. C. Tell me a story. Evanston, IL: Northwestern University Press, 1990

Silverman, L. H. "Visitor Meaning-Making in Museums for a New Age.” Curator: The Museum Journal, 38: (1995): 161-170

Taylor, J., Sharples, M., O’Malley, C., Vavoula, G. \& Waycott, J. Towards a task model for mobile learning: a dialectical approach. (2006) Available from http://kn.open.ac.uk/public/document.cfm?docid=5374,

Terras, M., Warwick, C., and Ross, C. "Building Useful Virtual Research Environments: The Need for Used-led Design.” In University Libraries and Digital Learning Environments, edited by Dale, P., Bears, J., and Holland, M. Ashgate, Surrey, Burlington, 2011: 151-167

Thomas,S and A. Mintz, Eds. The Virtual and the Real: Media in the Museum. Washington, DC, American Association of Museums. 1998.

Walker, K. "Narrative and Mobile Learning in Practice and Theory." Presented at the II Kaleidoscope workshop on Narrative Learning Environments, Palermo, Italy, 26-28 June 2006

Walker, K. "Structuring Visitor Participation." in Digital Technologies and the Museum Experience: Handheld Guides and Other Media, edited by L. Tallon and K.Walker, AltaMira Press, August 2008 